\title{
Effect of whey protein concentrate on texture of fat-free desserts: sensory and instrumental measurements
}

\author{
Efeito do concentrado protéico de soro na textura de sobremesas lácteas sem gordura: medidas
} sensorial e instrumental

\author{
Márcia Cristina Teixeira Ribeiro VIDIGAL ${ }^{1}$, Valéria Paula Rodrigues MINIM ${ }^{1 \star}$, Afonso Mota RAMOS ${ }^{1}$, \\ Elaine Berger CERESINO ${ }^{1}$, Mayra Darliane Martins Silva DINIZ ${ }^{1}$, Geany Peruch CAMILLOTO ${ }^{1}$, Luis Antonio MINIM ${ }^{1}$
}

\begin{abstract}
It is important to understand how changes in the product formulation can modify its characteristics. Thus, the objective of this study was to investigate the effect of whey protein concentrate (WPC) on the texture of fat-free dairy desserts. The correlation between instrumental and sensory measurements was also investigated. Four formulations were prepared with different WPC concentrations $(0,1.5,3.0$, and 4.5 wt. (\%)) and were evaluated using the texture profile analysis (TPA) and rheology. Thickness was evaluated by nine trained panelists. Formulations containing WPC showed higher firmness, elasticity, chewiness, and gumminess and clearly differed from the control as indicated by principal component analysis (PCA). Flow behavior was characterized as time-dependent and pseudoplastic. Formulation with $4.5 \% \mathrm{WPC}$ at $10{ }^{\circ} \mathrm{C}$ showed the highest thixotropic behavior. Experimental data were fitted to Herschel-Bulkley model. The addition of WPC contributed to the texture of the fat-free dairy dessert. The yield stress, apparent viscosity, and perceived thickness in the dairy desserts increased with WPC concentration. The presence of WPC promotes the formation of a stronger gel structure as a result of protein-protein interactions. The correlation between instrumental parameters and thickness provided practical results for food industries.
\end{abstract}

Keywords: fat-free dairy dessert; whey protein concentrate; sensory analysis; rheological properties; texture profile analysis.

\section{Resumo}

É importante entender como as mudanças na formulação de um alimento podem afetar suas características. Sendo assim, o objetivo deste trabalho foi estudar o efeito da adição de concentrado protéico de soro (CPS) na textura de sobremesas lácteas tipo flan sem gordura. A correlação entre as medidas instrumentais e sensoriais também foi investigada. Quatro formulações foram desenvolvidas com diferentes concentrações de CPS (0, 1,5, 3,0 e 4,5\% em massa) e avaliadas instrumentalmente por meio de análise de perfil de textura (TPA) e reologia. A consistência foi avaliada por nove julgadores treinados. As formulações adicionadas de CPS apresentaram maior firmeza, elasticidade, mastigabilidade e gomosidade em relação à amostra controle, como indicado na análise de componentes principais. O comportamento ao escoamento das sobremesas lácteas foi caracterizado como tempo-dependente e pseudoplástico. A formulação contendo 4,5\% de CPS a $10{ }^{\circ} \mathrm{C}$ apresentou maior comportamento tixotrópico. Os dados experimentais foram ajustados ao modelo de Herschel-Bulkley. A adição de CPS contribuiu para a textura das sobremesas lácteas sem gordura. Os valores de tensão inicial, viscosidade aparente e consistência das sobremesas lácteas aumentaram com a concentração de CPS. A presença de CPS promoveu uma estrutura de gel mais forte como resultado das interações proteína-proteína. A correlação entre os parâmetros instrumentais e a consistência sensorial forneceu informações práticas para a indústria de alimentos.

Palavras-chave: sobremesa láctea sem gordura; concentrado protéico de soro; análise sensorial; propriedades reológicas; análise de perfil de textura.

\section{Introduction}

In recent decades there has been increasing interest in the development of low-fat or fat-free products. People are motivated to consume low-fat dairy products in order to ensure overall good health and reduce the risk of several types of diseases, such as obesity, hypertension, cerebral apoplexy, and coronary heart diseases (SANDOVAL-CASTILLA et al., 2004; YOO et al., 2007). The formulation of these foods constitutes a great challenge for the food industry since fat has multiple properties which affect food texture, appearance, flavor and aroma (GONZÁLEZ-TOMÁS et al., 2008). Texture is an important parameter in formulated foods containing structuring agents such as proteins and polysaccharides. González-Tomás et al. (2008) studied the influence of two types of thickeners, starch and k-carrageenan, on the rheological and sensory properties of low-fat dairy desserts and observed differences in the orally perceived thickness.

The use of whey protein concentrate (WPC) in dairy products would be an alternative approach for maintaining the sensory properties by making them a more attractive product to the consumer. WPC has been considered an interesting fatsubstitute ingredient due to its functional and technological properties, as well as its nutritional appeal since it contains high concentrations of bioactive proteins. Whey protein functionality is associated to its composition and degree of denaturation (LIZARRAGA et al., 2006). Proteins are composed of uniform and spherical particles allowing the sliding

Received 22/11/2011

Accepted 01/02/2012 (005523)

${ }^{1}$ Department of Food Technology, Federal University of Viçosa - UFV, Av. Peter Henry Rolfs, s/n, CEP 36570000, Viçosa, MG, Brazil, e-mail: vprm@ufv.br ${ }^{*}$ Corresponding author 
of one particle over another offering the sense of creaminess. (PINHEIRO; PENNA, 2004). $\beta$-lactoglobulin is the major protein in whey, and it is considered the main gel-forming agent due to the presence of free sulfhydryl groups in the molecule. WPC has been used as a fat substitute in various foods such as yogurt (AZIZNIA et al., 2008; SANDOVAL-CASTILLA et al., 2004; LOBATO-CALLEROS et al., 2004), cheese (LOBATOCALLEROS et al., 2007), and sausage (YOO et al., 2007). Sandoval-Castilla et al. (2004) studied the addition of three commercial fat replacers consisting of whey protein concentrate (WPC), microparticulated whey protein (MWP), and modified tapioca starch (MTS), alone and combined. These authors reported that yogurt with WPC and blends of WPC and MWP have textural characteristics similar to those of fullfat yogurt.

Food texture comprises mechanical properties, tactile sensations, and also visual and audible stimuli. The texture properties are most accurately measured by sensory analysis techniques which use trained judges to detect and evaluate specific texture attributes. In order to reduce expenses and variability of tests with individuals, different instruments have been developed to simulate sensory perceptions (FOEGEDING, 2007). Recently, several studies on the rheological characterization of dairy desserts have been conducted (TORRES; TÁRREGA; COSTELL, 2010; DOUBLIER; DURAND, 2008; GONZÁLEZ-TOMÁS et al., 2008; DE WIJK; PRINZ; JANSSEN, 2006; GONZÁLEZTOMÁS; COSTELL, 2006), most with the purpose of relating sensory texture measurements and rheological data obtained by fluid flow and viscoelasticity characterization. Instrumental Texture Profile Analysis (TPA) has been effectively applied to many kinds of foods (KIM et al., 2009; LASSOUED et al., 2008; LEE et al., 1999; PONS; FISZMAN, 1996).

Based on rheological measurements, the product formulation can be modified to produce a more attractive food. Accordingly, the objective of the present study was to evaluate the effect of whey protein concentrate in fat-free dairy desserts by means of instrumental and sensory methods. (TPA) and rheological measurements were carried out and the results were correlated with sensory data obtained from a trained panel.

\section{Material and methods}

\subsection{Dairy Dessert elaboration}

The samples were produced with soluble WPC (33\% protein) (Gemacom, Juiz de Fora, Brazil), k-carrageenan (Griffith, Mogi das Cruzes, Brazil), commercial skimmed-milk powder (Itambé, Sete Lagoas, Brazil), corn starch (Unilever, Mogi Guaçu, Brazil), sucrose, and a vanila flavour (Duas Rodas, Jaraguá do Sul, Brazil).

Four dairy desserts (Control, F1, F2, and F3) were formulated with different concentrations of WPC $(0,1.5,3.0$, and $4.5 \mathrm{wt}$. \%), respectively. The concentrations of sugar (12.0 wt. $\%)$, skimmed-milk powder (10.0 wt. \%), corn starch (5.0 wt. \%), vanilla flavor (2.5 wt. \%), and k-carrageenan (0.02 wt. \%) were kept constant. The solids were mixed with water in a dry pan and the mixture was maintained under agitation in a water bath at $40^{\circ} \mathrm{C}$ for 2 minutes. Subsequently, the temperature was increased to $90 \pm 2{ }^{\circ} \mathrm{C}$ for 15 minutes for pasteurization. The temperature was then reduced to $40^{\circ} \mathrm{C}$, vanilla flavor was added, and the mixing continued for another 2 minutes. The samples were put in plastic cups, covered to avoid drying, and stored under refrigeration $\left(4 \pm 1^{\circ} \mathrm{C}\right)$ until instrumental and sensory analysis. Three batches were prepared for each dessert.

\subsection{Texture profile analysis}

TPA was carried out using the universal testing machine (Instron - Series 3367, United Stated, 2005) with a $0.05 \mathrm{~N}$ load cell. Compression measurements were conducted at $10{ }^{\circ} \mathrm{C}$ using a probe $50 \mathrm{~mm}$ diameter to apply $20 \%$ constant strain to a sample of $50 \mathrm{~mm}$ diameter and $40 \mathrm{~mm}$ height (PONS; FISZMAN, 1996). The test speed was $2 \mathrm{~mm} / \mathrm{s}$ with two penetration cycles. The force exerted on the sample was automatically recorded, and the parameters of firmness $(\mathrm{N})$, chewiness $(\mathrm{J})$, gumminess $(\mathrm{N})$, cohesiveness (dimensionless), adhesiveness (N.s), and elasticity ( $\mathrm{mm}$ ) were automatically evaluated from the force $(\mathrm{N}) \times$ time $(\mathrm{s})$ curves generated during the test by the Blue Hill 2.0 software (Instron, United States, 2005). A fresh sample was used for each measurement. Three batches of each composition were prepared, and at least five measurements were performed on each batch.

\subsection{Rheological analysis}

Rheological analyses were performed with a rotational rheometer (Brookfield, R/S plus SST 2000 model) and a coaxial cylinder sensor CC14 (inner cylinder radius of 7 and $21 \mathrm{~mm}$ in length and outer cylinder radius of $7.59 \mathrm{~mm}$ ). The measurements were taken under constant temperatures of 10 and $25{ }^{\circ} \mathrm{C}$, selected as representative of common dairy dessert temperature for consumption and oral temperature developed during consumption of the semi-solids foods, respectively (TÁRREGA; DURAN; COSTELL, 2005; ENGELEN et al., 2003). A fresh sample was loaded for each rheological measurement. Three batches of each composition were prepared, and at least two measurements were performed on each batch.

Thixotropic characterization was carried out under constant shear rate of $10 / \mathrm{s}$ for a period of 10 minutes at temperatures of 10 and $25^{\circ} \mathrm{C}$. The shear measurements were taken at 6- second intervals for 10 minutes totalizing 100 points in each test.

The model of Figone and Shoemaker (Equation 1) was used to describe the time dependent flow properties of the samples:

$\tau(t)=\tau_{e}+\left(\tau_{0}-\tau_{e}\right) \cdot e^{-k_{i} \cdot t}$

where $\tau(\mathrm{t})$ is the shear stress $(\mathrm{Pa})$ at a given time $(\mathrm{s}), \tau_{e}$ is the shear stress at equilibrium $(\mathrm{Pa}), \tau_{0}$ is the initial shear stress $(\mathrm{Pa})$, and $K_{i}(/ \mathrm{s})$ is the constant of the structural destruction kinetic.

Rheological measurements were carried out in a controlled stress mode. Flow curves were obtained by progressively increasing the shear rate $(\gamma)$ to $200 /$ s for 120 seconds, followed by a decreasing over the same time period. The average shear 
Table 1. Values of instrumental texture parameters for fat-free dairy desserts with different concentrations $(0,1.5,3.0$, and 4.5 wt. (\%)) of WPC (Control, F1, F2, and F3, respectively).

\begin{tabular}{|c|c|c|c|c|c|}
\hline Formulations & $\begin{array}{l}\text { Firmness } \\
(\mathrm{N})\end{array}$ & $\begin{array}{c}\text { Elasticity } \\
(\mathrm{mm})\end{array}$ & $\begin{array}{c}\text { Cohesiveness } \\
\text { (dimensionless) }\end{array}$ & $\begin{array}{c}\text { Chewiness } \\
(\mathrm{J})\end{array}$ & $\begin{array}{c}\text { Gumminess } \\
(\mathrm{N})\end{array}$ \\
\hline Control & $1.18 \pm 0.03$ & $4.51 \pm 0.35$ & $0.90 \pm 0.07$ & $5.48 \pm 1.24$ & $0.76 \pm 0.15$ \\
\hline $\mathrm{F} 1$ & $1.33 \pm 0.03$ & $4.90 \pm 0.29$ & $0.91 \pm 0.02$ & $6.51 \pm 0.27$ & $0.89 \pm 0.04$ \\
\hline F2 & $1.49 \pm 0.05$ & $4.95 \pm 0.14$ & $0.91 \pm 0.01$ & $7.31 \pm 0.26$ & $0.99 \pm 0.02$ \\
\hline F3 & $1.48 \pm 0.06$ & $4.91 \pm 0.14$ & $0.88 \pm 0.01$ & $6.55 \pm 0.51$ & $0.89 \pm 0.09$ \\
\hline
\end{tabular}

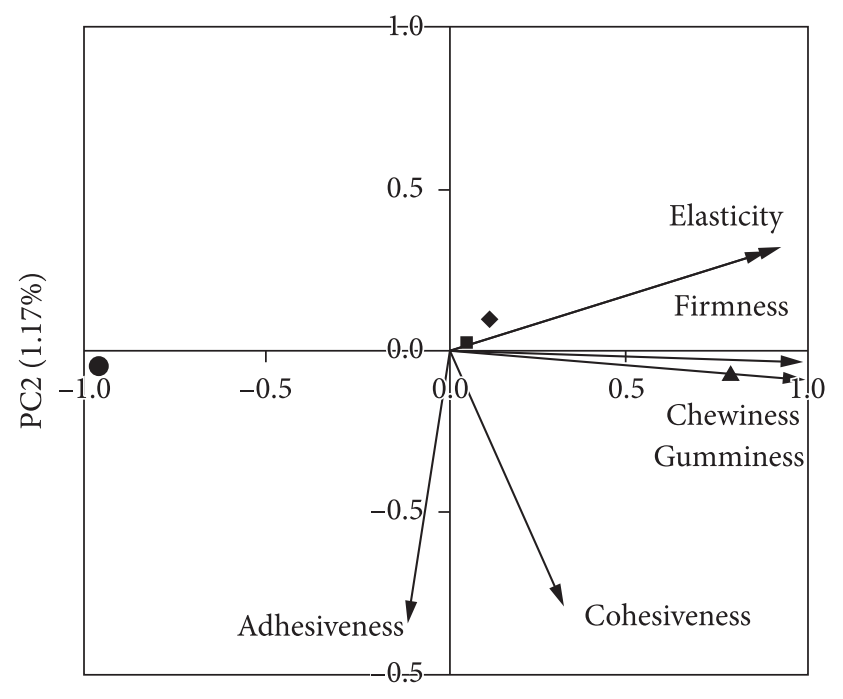

PC1 $(98.38 \%)$

Figure 1. Principal Component Analysis of instrumental texture parameters for fat-free dairy desserts with different concentrations $(0,1.5,3.0$, and 4.5 wt. $(\%))$ of WPC (• Control, $\bullet \mathrm{F} 1, \Delta \mathrm{F} 2$, and $\bullet \mathrm{F} 3$, respectively).

stress for each shear rate was evaluated. Before each experiment, a constant shear rate of $100 / \mathrm{s}$ was applied for 3 minutes for thixotropy breakdown.

The Hershel-Bulkley (Equation 2) model was adjusted to the rheological data:

$$
\tau=\tau_{0}+K \dot{\gamma}^{n}
$$

where: $\tau$ is the shear stress $(\mathrm{Pa}), \dot{\gamma}$ is the shear rate $(/ \mathrm{s}), \tau_{0}$ is the yield stress $(\mathrm{Pa}), K$ is the consistency index $\left(\mathrm{Pa} . \mathrm{s}^{n}\right)$, and $n$ is the flow behavior index (dimensionless). Apparent viscosity at $10 / \mathrm{s}$ was obtained from the equation of Herschel-Bulkley.

\subsection{Sensory evaluation}

The sensory characterization of the formulations was carried out by means of Quantitative Descriptive Analysis (QDA) by a trained panel (STONE et al., 1974; STONE; SIDEL, 1998). Thickness was one of the eight attributes assessed by the trained panel according to ISO 11036:1994 (INTERNATIONAL..., 1994). Thickness evaluation was conducted in a standardized room (ISO 8589) (INTERNATIONAL..., 1988), with white fluorescent lighting. The panelists were selected based on their ability to discriminate the samples and their repeatability.

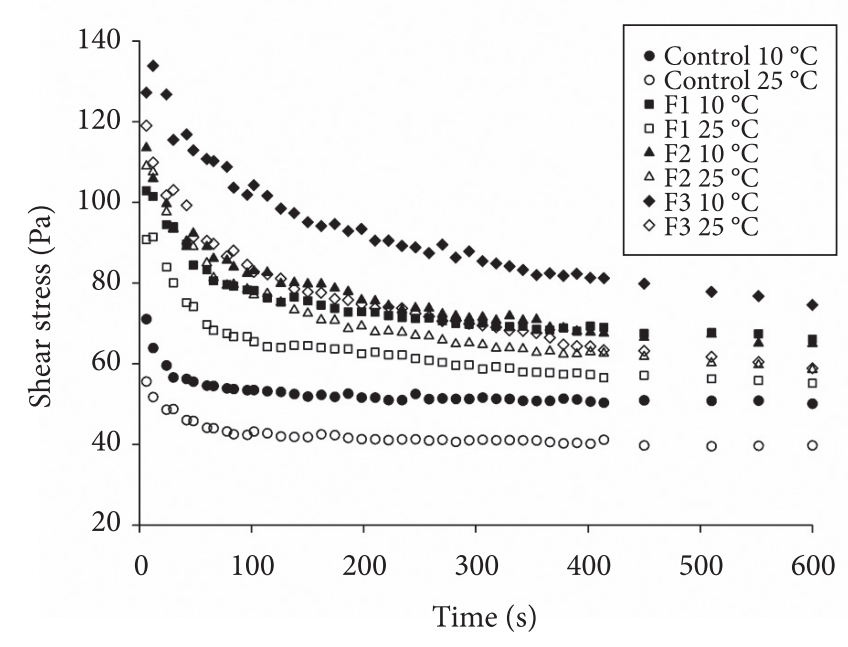

Figure 2. Variation of shear stress over time for fat-free dairy desserts with different concentrations $(0,1.5,3.0$, and 4.5 wt. (\%)) of WPC (Control, F1, F2, and F3, respectively) at 10/s for at temperatures of 10 and $25^{\circ} \mathrm{C}$.

The sample thickness was evaluated by nine-member trained panel using a $9-\mathrm{cm}$ non-structured linear scale anchored at the extremities with terms that express intensity (very and little). Chilled samples $\left(10^{\circ} \mathrm{C}\right)$ were presented to the panelists at room temperature $\left(25^{\circ} \mathrm{C}\right)$. In the final evaluation, the four samples were coded with three digit numbers and shown simultaneously in three sessions. Mineral water was used to rinse the mouth between consecutive samples.

\subsection{Statistical analysis}

One-factor (sample) ANOVA was applied to the instrumental data. Principal Component Analysis (PCA) with varimax rotation was applied to the correlation matrix of the average values of instrumental texture parameters.

The experimental data of thixotropy and flow behavior were fitted to Figone \& Shoemaker and Hershel-Bulkley models, respectively. The quality of the model fit was verified according to the significance level ( $p)$ and determination coefficient $\left(R^{2}\right)$.

Sensory data was analyzed by ANOVA and regression analysis. The correlation between the instrumental and sensory texture measurements was determined using the Pearson correlation coefficient (r). All analyses were performed using the SAS statistical software version 9.1 (SAS Institute, Inc., Cary, NC, USA). 
Table 2. Values of rheological parameters of Figoni-Shoemaker equation for fat-free dairy desserts with different concentrations $(0,1.5,3.0$, and 4.5 wt. (\%)) of WPC (Control, F1, F2, and F3, respectively).

\begin{tabular}{ccccccc}
\hline $\mathrm{T}\left({ }^{\circ} \mathrm{C}\right)$ & Formulation & \multicolumn{1}{c}{$\tau_{0}(\mathrm{~Pa})$} & $\tau_{\mathrm{e}}(\mathrm{Pa})$ & $\left(\tau_{0}-\tau_{\mathrm{e}}\right)(\mathrm{Pa})$ & $K_{i}(/ \mathrm{s})$ & $\mathrm{R}^{2}$ \\
\hline 10 & Control & $70.99 \pm 0.81$ & $51.25 \pm 0.09$ & $19.74 \pm 0.72$ & $0.030 \pm 0.002$ & 0.930 \\
& F1 & $102.45 \pm 0.82$ & $67.98 \pm 0.21$ & $34.47 \pm 0.61$ & $0.012 \pm 0.000$ & 0.967 \\
& F2 & $103.50 \pm 0.95$ & $65.85 \pm 0.48$ & $37.65 \pm 0.47$ & $0.007 \pm 0.000$ & 0.956 \\
& F3 & $127.63 \pm 0.82$ & $74.96 \pm 0.58$ & $52.67 \pm 0.26$ & $0.006 \pm 0.000$ & 0.981 \\
& Control & $54.63 \pm 0.54$ & $40.41 \pm 0.09$ & $14.22 \pm 0.45$ & $0.018 \pm 0.001$ & 0.930 \\
& F1 & $90.08 \pm 1.03$ & $57.27 \pm 0.25$ & $32.81 \pm 0.78$ & $0.012 \pm 0.001$ & 0.946 \\
& F2 & $106.41 \pm 0.91$ & $60.68 \pm 0.31$ & $45.72 \pm 0.60$ & $0.009 \pm 0.000$ & 0.975 \\
& F3 & $109.73 \pm 1.01$ & $60.29 \pm 0.58$ & $49.44 \pm 0.43$ & $0.006 \pm 0.000$ & 0.970 \\
\hline
\end{tabular}

$\tau_{0}$ : initial stress; $\tau$ : shear stress at equilibrium; $\left(\tau_{0}-\tau\right)$ : break-down structure during shearing; $K$ : structural degradation kinetic constant. Control (without WPC addition), F1 (1.5\% of WPC), F2 (3.0\% of WPC) and F3 (4.5\% of WPC).

\subsection{Ethics committee}

This project was analyzed and approved by the Scientific Graduate Committee of the Department of Food Technology - Federal University of Viçosa, process $\mathrm{n}^{\mathrm{o}}$. 50717257515/2009, complying as outlined, with the necessary requirements for its publication.

\section{Results and discussion}

\subsection{Texture Profile Analysis (TPA)}

Average values and associated uncertainties of texture parameters of the samples are presented in Table 1. The results of the ANOVA indicated that the addition of WPC affected the parameters of firmness, elasticity, chewiness, and gumminess $(\mathrm{p}<0.10)$.

The Principal Component Analysis (PCA) of average texture parameters showed that the first two components accounted for $99.55 \%$ of the total variability of the data, with the first component explaining 98.38\%. Figure 1 shows the correlation of instrumental texture parameters and the spatial arrangement of samples in relation to the two principal components. The first principal component (PC1) was strongly associated with elasticity, firmness, chewiness, and gumminess, and it clearly separated the control sample from the others. These results indicated that the addition of WPC to the formulations contributed to enhance textural properties, except for adhesiveness and cohesiveness, which is attributed to its high water retention capacity and gelling properties. This is in agreement with the results presented by Antunes, Motta and Antunes (2003), who reported that $\beta$-lactoglobulin is the main gelling agent due to the presence of free sulfhydryl groups. Formulations supplemented with WPC showed greater elasticity. This parameter is strongly related to the formation of intermolecular disulfide bonds (SHIMADA; CHEFTEL, 1989). The second principal component (PC2) is associated with the parameters adhesiveness $(\mathrm{r}=-0.84)$ and cohesiveness $(\mathrm{r}=-0.78)$. PC2 explains only $1.17 \%$ of total data variation indicating that there was no difference between the samples in terms of adhesiveness and cohesiveness.

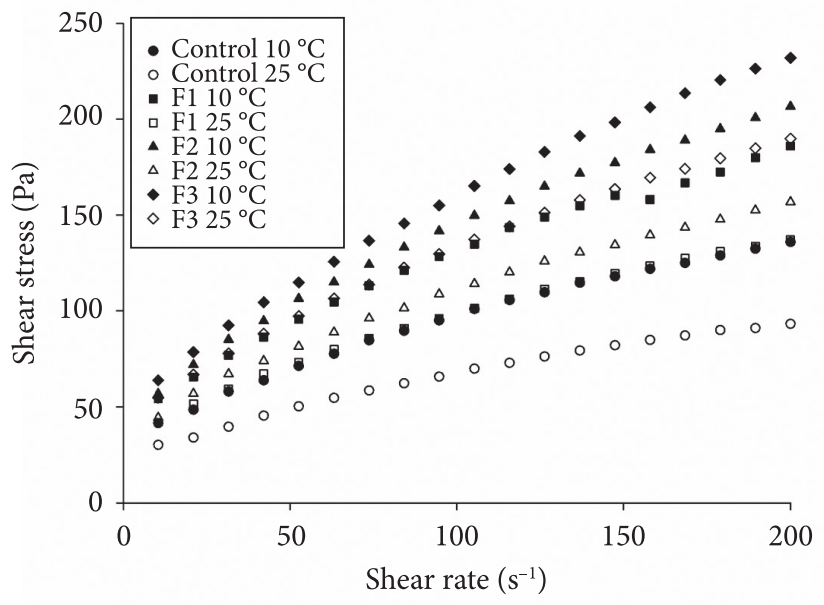

Figure 3. Experimental results of the shear rate sweep tests for fat-free dairy desserts with different concentrations $(0,1.5,3.0$, and $4.5 \mathrm{wt}$. (\%)) of WPC (Control, F1, F2, and F3, respectively) at temperatures of 10 and $25^{\circ} \mathrm{C}$

\subsection{Rheological analysis}

\section{Thixotropic characterization}

The thixograms obtained for the shear stress versus time, at constant shear rate of $10 / \mathrm{s}$, showed time dependency at both temperatures of 10 and $25{ }^{\circ} \mathrm{C}$ (Figure 2). Shear stress decayed with time, and this behavior is similar to that found by González-Tomás and Costell (2006) and Tárrega and Costell (2007) in commercial dairy desserts. It is observed that thixotropy presented two stages. In the first stage, there was a significant shear stress decay due to sample disintegration. In the second stage, the decay was slower due to the change of particle orientation caused by deformation. This behavior was found by several authors (RAMOS; IBARS, 1998; ABU-JDAYIL, 2003; BASU; SHIVHARE; RAGHAVAN, 2007) during the thixotropic characterization of orange juice and quince pulp, and pineapple jelly, and concentrated yogurt, respectively.

The model of Figone \& Shoemaker was satisfactorily fit to the experimental data with values of $\mathrm{R}^{2}$ greater than 0.930 (Table 2). It is observed that the amount of structure degradation during shear stress $\left(\tau_{0}-\tau_{e}\right)$ increases when the 
Table 3. Steady-state parameters of Herschel-Bulkley equation for fat-free dairy desserts with different concentrations $(0,1.5,3.0$, and 4.5 wt. (\%)) of WPC (Control, F1, F2, and F3, respectively).

\begin{tabular}{|c|c|c|c|c|c|c|}
\hline$T\left({ }^{\circ} \mathrm{C}\right)$ & Formulation & $\tau_{0}(\mathrm{~Pa})$ & $K\left(\mathrm{~Pa} \times \mathrm{s}^{\mathrm{n}}\right)$ & $n$ & $R^{2}$ & $\eta_{10}(\mathrm{~Pa} \times \mathrm{s})$ \\
\hline \multirow[t]{4}{*}{10} & Control & $18.41 \pm 2.85$ & $5.22 \pm 0.83$ & $0.59 \pm 0.03$ & 0.998 & 3.87 \\
\hline & F1 & $23.21 \pm 5.59$ & $7.28 \pm 1.65$ & $0.58 \pm 0.04$ & 0.997 & 5.12 \\
\hline & F2 & $24.66 \pm 2.35$ & $7.58 \pm 0.66$ & $0.60 \pm 0.01$ & 0.999 & 5.49 \\
\hline & F3 & $35.23 \pm 2.36$ & $5.59 \pm 0.52$ & $0.67 \pm 0.02$ & 0.999 & 6.16 \\
\hline \multirow[t]{4}{*}{25} & Control & $14.24 \pm 2.32$ & $3.41 \pm 0.66$ & $0.59 \pm 0.03$ & 0.998 & 2.78 \\
\hline & $\mathrm{F} 1$ & $20.44 \pm 1.64$ & $5.15 \pm 0.48$ & $0.59 \pm 0.02$ & 0.999 & 4.05 \\
\hline & F2 & $20.22 \pm 1.77$ & $6.03 \pm 0.51$ & $0.59 \pm 0.01$ & 0.999 & 4.36 \\
\hline & F3 & $28.04 \pm 2.05$ & $5.70 \pm 0.52$ & $0.63 \pm 0.02$ & 0.999 & 5.25 \\
\hline
\end{tabular}

$\tau_{0}$ : yield stress, $K$ : consistency index, $n$ : flow behavior index, $\eta_{10}$ : apparent viscosity under shear rate of $10 / s$.

concentration of WPC increases. According to Corrêa et al. (2005), elevating the thixotropy tends to increase the product shelf-life because it presents higher viscosity during storage, which complicates component separation. This is due to the greater energy required to disrupt the structure responsible for the time dependent behavior. The structure-degradation kinetic constant $\left(K_{i}\right)$ decreased as WPC concentration increased for both temperatures. In other words, the control sample reached equilibrium faster suggesting that the increase in WPC concentration forms a stronger gel structure as a result of strong protein-protein interactions, and consequently the rate of gel structure degradation is greater.

\section{Fluid flow behavior characterization}

Figure 3 shows the flow curves of the four formulations studied at 10 and $25{ }^{\circ} \mathrm{C}$. All samples showed non-Newtonian shear-thinning flow with an apparent yield stress. This behavior is in accordance with that observed by other authors in similar products (WISCHMANN; NORSKER; ADLER-NISSEN, 2002; TÁRREGA; COSTELL, 2007).

The Herschel-Bulkley model presented good fit showing greater values for the determination coefficient in the studied temperatures $\left(\mathrm{R}^{2}>0.997\right)$. The samples were clearly pseudoplastic showing flow behavior indices $(n)$ in the range of 0.58 to 0.67 (Table 3). According to Table 3, for a given temperature the yield stress values increased with the increase in WPC concentration. The yield stress represents the magnitude of plasticity and indicates the resistance of dairy desserts to permanent deformation (KEALY, 2006). Therefore, the structural resistance to flow tends to rise as the WPC concentration increases suggesting an increasing of internal structural stiffness.

Apparent viscosity under shear rate of $10 / \mathrm{s}$ was evaluated from the equation of Herschel-Bulkley. According to Shama and Sherman (1973), this apparent viscosity was selected as a potential practical index of sensory viscosity since it is suggested that the physical stimulus of sensory viscosity varies with flow characteristics, and for more viscous food, these stimuli appear to be related to the shear stress developed at a constant shear rate of 10/s. It is observed that apparent viscosity increased as WPC concentration increased for both temperatures.

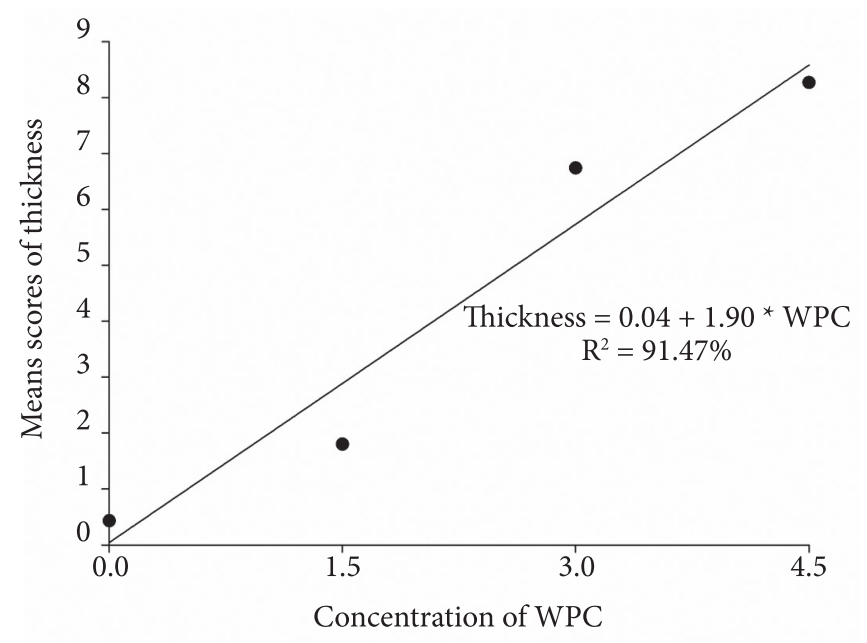

Figure 4. Sensory evaluation of thickness for fat-free dairy desserts with different concentrations of WPC.

\subsection{Sensory analysis}

The results obtained from the ANOVA with two sources of variation (sample and panelist) and sample versus panelist interaction showed significant differences $(p<0.05)$ in the thickness of samples.

The formulations F1, F2, F3, and control, showed mean scores of $1.8,6.7,8.3$, and 0.43 , respectively, for the thickness attribute. The control formulation showed minimal thickness while the sample F3, with $4.5 \%$ WPC, presented the highest intensity value for this attribute. It is observed that there is an increase in thickness with the increase in WPC indicating its efficiency in enhancing texture (Figure 4).

\subsection{Relationship between instrumental and sensory data}

The assessments of thickness, obtained by the trained taste panel, TPA (measuring firmness, chewiness, gumminess, cohesiveness, adhesiveness, and elasticity) and rheological properties (measuring flow curve parameters and thixotropy) were used for determining the correlation between instrumental and sensory measurements using the Pearson analysis.

Considering the thixotropic parameters, structure breakdown during shearing $\left(\tau_{0}-\tau_{e}\right)$ showed significant 
correlation with thickness, according to the trained panel, at both temperatures $\left(\mathrm{r}=0.87\right.$ at $10{ }^{\circ} \mathrm{C}$ and $\mathrm{r}=0.91$ at $\left.25^{\circ} \mathrm{C}\right)$. Higher values of this parameter result in a more solid-like behavior of the product resulting in more consistent sample. The structure-degradation kinetic constant $\left(K_{i}\right)$ did not significantly correlate $(\mathrm{p}>0.20)$ with oral thickness at $10^{\circ} \mathrm{C}$, but it showed significant negative correlation $(r=-0.90)$ at $25^{\circ} \mathrm{C}$.

Oral thickness was also correlated to yield stress $\left(\tau_{0}\right)$ $\left(\mathrm{r}=0.85\right.$ at $10^{\circ} \mathrm{C}$ and $\mathrm{r}=0.81$ at $\left.25^{\circ} \mathrm{C}\right)$ and apparent viscosity at $10 / \mathrm{s}(\mathrm{r}=0.87$ for both temperatures). According to Van Vliet (2002), the thickness of a product is related to the yield stress, which is the force required to start flow. It is expected that this measurement is similar to that observed by the panelist when evaluating thickness of food products. The correlation between oral thickness and $\eta_{10}$ corroborates the proposal of Shama and Sherman (1973). These authors proposed that the apparent viscosity values under a stress rate of $10 / \mathrm{s}$ can result in an oral thickness index for semi-solid products. When evaluating commercial dairy desserts, Tárrega and Costel (2007) also found good correlation $(\mathrm{p} \leq 0.14)$ between oral thickness and yield stress $\left(\tau_{0}\right)$ and apparent viscosity at $10 / \mathrm{s}$ and $25^{\circ} \mathrm{C}$. The flow behavior index $(n)$ was not correlated $(\mathrm{p}>0.21)$ with oral thickness at the two studied temperatures. The consistency index $(K)$ at $25^{\circ} \mathrm{C}$ correlated positively $(\mathrm{r}=0.80)$ with the sensory texture attribute. These results suggest that rheological analysis at $25^{\circ} \mathrm{C}$ provide parameters which better correlate with thickness perception. According to Engelen et al. (2003), $25^{\circ} \mathrm{C}$ is the oral temperature developed during the consumption of the dairy desserts at $10^{\circ} \mathrm{C}$.

The correlation between the perceived thickness and the instrumental texture parameters was also determined. the oral thickness of dairy desserts showed significant correlation $(r=0.92)$ with instrumental firmness values. This result corroborates those found by Saint-Eve et al. (2009) investigating the effect of reducing salt and fat content on composition, texture, and sensory properties of flavoured model dairy products. These authors reported high correlation $(r=0.97)$ between firmness perception and firmness TPA parameters. The parameters of elasticity, cohesiveness, gumminess, and chewiness did not significantly correlate with this sensory property $(p>0.32)$. The non-correlation of these parameters can be attributed to differences between the chewing process and instrumental methodology used. The temperature during samples evaluation may have been a limiting factor since the tests were conducted at refrigeration temperature of samples while the oral temperature developed during the consumption of the dairy desserts is $25^{\circ} \mathrm{C}$. However, many authors describe the instrumental texture analysis (TPA) at refrigeration temperature (LOBATO, 2006; RICHTER, 2006; HUANG et al., 2007).

\section{Conclusion}

The formulations supplemented with WPC showed greater elasticity, firmness, chewiness, and gumminess compared to the control sample thus contributing to the texture of the fatfree dairy desserts. All formulations presented pseudoplastic behavior, yield stress, and thixotropy. The addition of WPC led to an increase in yield stress, thixotropy, apparent viscosity at the shear rate of $10 / \mathrm{s}$, and perceived thickness in fat-free dairy desserts. The formulation with $4.5 \% \mathrm{WPC}$ had the strongest gel structure, which is the result of more protein-protein interactions.

Several instrumental parameters including TPA firmness, yield stress $\tau_{0}$, thixotropic parameters $\left(\tau_{0}-\tau_{e}\right)$, and $K_{i}$, and apparent viscosity $\eta_{10}$ showed good correlation with oral thickness, especially at $25^{\circ} \mathrm{C}$. Therfore, these instrumental parameters can replace the sensory evaluation of texture, which is rarely used in the food industry due to cost and time required to train a sensory panel.

The textural relationships between the trained panelist, TPA, and rheometry are based on the physico-chemical nature of the products. Rheological properties and instrumental texture of the fat-free desserts were affected by WPC content leading to significant differences in the orally perceived thickness.

\section{Acknowledgements}

The authors are grateful to CNPq and FAPEMIG for the financial support.

\section{References}

ABU-JDAYIL, B. Modelling the time-dependent rheological beahaviour of semisolid foodstuffs. Journal of Food Engineering, v. 57, p. 97-102, 2003. http://dx.doi.org/10.1016/S0260-8774(02)00277-7

ANTUNES, A. E. C.; MOTTA, E. M. P.; ANTUNES, A. J. Perfil de textura e capacidade de retenção de água de géis ácidos de concentrado protéico de soro de leite. Ciência e Tecnologia de Alimentos, v. 23, p. 183-189, 2003. http://dx.doi.org/10.1590/ S0101-20612003000400034

AZIZNIA, S. et al. Whey Protein Concentrate and Gum Tragacanth as Fat Replacers in Nonfat Yogurt: Chemical, Physical, and Microstructural Properties. Journal of Dairy Science, v. 91, n. 7, p. 2545-2552, 2008. PMid:18565911. http://dx.doi.org/10.3168/ jds.2007-0875

BASU, S.; SHIVHARE, U. S.; RAGHAVAN, G. S. V. Time dependent rheological characteristics of pineapple jam. International Journal of Food Engineering, v. 3, n. 3, 2007.

CORRÊA, N. M. et al. Avaliação do comportamento reológico de diferentes géis hidrofílicos. Journal of Pharmaceutical Sciences, v. 41, n. 1, p. 73-78, 2005.

DE WIJK, R. A.; PRINZ, J. F.; JANSSEN, A. M. Explaining perceived oral texture of starch-based custard desserts from standard and novel instrumental tests. Food Hydrocolloid, v. 20, p. 24-34, 2006. http://dx.doi.org/10.1016/j.foodhyd.2005.02.008

DOUBLIER, J. L.; DURAND, S. A rheological characterization of semisolid dairy systems. Food Chemistry, v. 108, p. 1169-1175, 2008. http://dx.doi.org/10.1016/j.foodchem.2007.05.080

ENGELEN, L. et al. The effect of oral and product temperature on the perception of flavor and texture attributes of semi-solids. Appetite, v. 41, p. 273-281, 2003. http://dx.doi.org/10.1016/S01956663(03)00105-3

FOEGEDING, E. A. Rheology and sensory texture of biopolymer gels. Current Opinion in Colloid \& Interface Science, v. 12, p. 242-250, 2007. http://dx.doi.org/10.1016/j.cocis.2007.07.001 
GONZÁLEZ-TOMÁS, L.; COSTELL, E. Relation between consumers' perceptions of color and texture of dairy desserts and instrumental measurements using a generalized procrustes analysis. Journal of Dairy Science, v. 89, p. 4511-4519, 2006. http://dx.doi.org/10.3168/ jds.S0022-0302(06)72499-7

GONZÁLEZ-TOMÁS, L. et al. Rheology, flavour release and perception of low-fat dairy desserts. International Dairy Journal, v. 18, p. 858-866, 2008. http://dx.doi.org/10.1016/j.idairyj.2007.09.010

HUANG, M. et al. Characters of rice starch gel modiWed by gellan, carrageenan, and glucomannan: A texture profile analysis study. Carbohydrate Polymers, v. 69, p. 411-418, 2007. http://dx.doi. org/10.1016/j.carbpol.2006.12.025

INTERNATIONAL ORGANIZATION FOR STANDARDIZATION - ISO. ISO 11036:1994: Sensory analysis: Methodology - Texture profile. Geneva: ISO, 1994.

INTERNATIONAL ORGANIZATION FOR STANDARDIZATION - ISO. ISO 8589:1988: Sensory analysis: Guide to design of test rooms for sensory analysis of food. Geneva: ISO, 1988.

KEALY, T. Application of liquid and solid rheological technologies to the textural characterization of semi-solid foods. Food Research International, v. 39, p. 265-276, 2006. http://dx.doi.org/10.1016/j. foodres.2005.07.016

KIM, E. H. J. et al. Predicting the sensory texture of cereal snack bars using instrumental measurements. Journal of Texture Studies, v. 40 , n. 4 , p. 457-481, 2009. http://dx.doi.org/10.1111/j.17454603.2009.00192.x

LASSOUED, N. et al. Baked product texture: Correlations between instrumental and sensory characterization using Flash Profile. Journal of Cereal Science, v. 48, p. 133-143, 2008. http://dx.doi. org/10.1016/j.jcs.2007.08.014

LEE, S. Y. et al. Relating descriptive analysis and instrumental texture data of processed diced tomatoes. Food Quality and Preference, v. 10 , n. 6 , p. 447-455, 1999. http://dx.doi.org/10.1016/S09503293(99)00035-X

LIZARRAGA, M. S. et al. Rheological behavior of whey protein concentrate and $\lambda$-carrageenan aqueous mixtures. Food Hydrocolloid, v. 20, p. 740-748, 2006. http://dx.doi.org/10.1016/j. foodhyd.2005.07.007

LOBATO, L. P. Efeito combinado de inulina, amido e leite nas características texturais e sensoriais de pudins. 2006. $122 \mathrm{f}$. Tese (Mestrado em Ciência de Alimentos)-Universidade Estadual de Londrina, Londrina, 2006.

LOBATO-CALLEROSA, C. et al. Flow and creep compliance properties of reduced-fat yoghurts containingprotein-based fat replacers. International Dairy Journal, v. 14, p. 777-782, 2004. http://dx.doi. org/10.1016/j.idairyj.2004.02.012

LOBATO-CALLEROSA, C. et al. Microstructure and texture of white fresh cheese made with canola oil and whey protein concentrate in partial or total replacement of milk fat. Food Research International, v. 40, p. 529-537, 2007. http://dx.doi.org/10.1016/j. foodres.2006.10.011

PINHEIRO, M. V. S.; PENNA, A. L. B. Substitutos de gordura: tipos e aplicações em produtos lácteos. Alimentos e Nutrução, v. 15, n. 2 , p. 175-186, 2004.
PONS, M.; FISZMAN, S. M. Instrumental texture profile analysis with particular reference to gelled systems. Journal of Texture Studies, v. 27, p. 597-624, 1996. http://dx.doi.org/10.1111/j.1745-4603.1996. tb00996.x

RAMOS, A. M.; IBARZ, A. Thixotropy of orange concentrate and quince puree. Journal of Texture Studies, n. 29, p. 313-324, 1998. http://dx.doi.org/10.1111/j.1745-4603.1998.tb00173.x

RICHTER, V. B. Desenvolvimento de uma técnica descritiva por ordenação. 2006. 74 f. Tese (Mestrado em Ciência de Alimentos)Universidade Estadual de Londrina, Londrina, 2006.

SANDOVAL-CASTILLA, O. et al. Microstructure and texture of yogurt as influenced by fat replacers. International Dairy Journal, v. 14, p. 151-159, 2004. http://dx.doi.org/10.1016/S0958-6946(03)00166-3

SAINT-EVE, A. et al. Reducing salt and fat content: Impact of composition, texture and cognitive interactions on the perception of flavoured model cheeses. Food Chemistry, v. 116, p. 167-175, 2009. http://dx.doi.org/10.1016/j.foodchem.2009.02.027

SHAMA, F.; SHERMAN, P. Identification of stimuli controlling the sensory evaluation of viscosity. II. Oral methods. Journal of Texture Studies, v. 4, p. 111-118, 1973. http://dx.doi. org/10.1111/j.1745-4603.1973.tb00657.x

SHIMADA, K.; CHEFTEL, J. C. Texture characteristics, protein solubility, and sulphydryl group/ disulfide bond content of heatinduced gels of whey protein isolate. Journal of Agricultural and Food Chemistry, v. 36, p. 1018-1025, 1989. http://dx.doi. org/10.1021/jf00083a029

STONE, H.; SIDEL, J. Quantitative descriptive analysis: Developments, applications and the future. Food Technology, v. 52, n. 8, p. 48-52, 1998.

STONE, H. et al. Sensory evaluation by quantitative descriptive analysis. Food Technology, v. 28, n. 11, p. 24-34, 1974.

TÁRREGA, A.; COSTELL, E. Colour and consistency of semi-solid desserts: Instrumental and sensory measurements. Journal of Food Engineering, v. 78, p. 655-661, 2007. http://dx.doi.org/10.1016/j. jfoodeng.2005.11.003

TÁRREGA, A.; DURAN, L.; COSTELL, E. Rheological characterization of semisolid dairy desserts. Effect of temperature. Food Hydrocolloid, v. 19, p. 133-139, 2005. http://dx.doi.org/10.1016/j. foodhyd.2004.04.022

TORRES, J. D.; TÁRREGA, A.; COSTELL, E. Storage stability of starch-based dairy desserts containing long-chain inulin: Rheology and particle size distribution. International Dairy Journal, v. 20, n. 1, p. 46-52, 2010. http://dx.doi.org/10.1016/j.idairyj.2009.08.001

VAN VLIET, T. On the relation between texture perception and fundamental mechanical parameters for liquids and time dependent solids. Food Quality and Preference, v. 13, p. 227-236, 2002. http:// dx.doi.org/10.1016/S0950-3293(01)00044-1

WISCHMANN, B.; NORSKER, M.; ADLER-NISSEN, J. Food product models developed to evaluate starch as food ingredient. Nahrung/ Food, v. 46, p. 167-173, 2002.

YOO, S. S. et al. Physicochemical characteristics, textural properties and volatile compounds in comminuted sausages as affected by various fat levels and fat replacers. International Journal of Food Science \& Technology, v. 42, n. 9, p. 1114-1122, 2007. http://dx.doi. org/10.1111/j.1365-2621.2006.01402.x 